University of Nebraska - Lincoln

DigitalCommons@University of Nebraska - Lincoln

\title{
Use of a Classroom Response System to Enhance Classroom Interactivity
}

\author{
Keng Siau \\ University of Nebraska - Lincoln, siauk@mst.edu \\ Hong Sheng \\ University of Nebraska - Lincoln \\ Fiona Fui-Hoon Nah \\ University of Nebraska - Lincoln
}

Follow this and additional works at: https://digitalcommons.unl.edu/managementfacpub

Part of the Management Sciences and Quantitative Methods Commons

Siau, Keng; Sheng, Hong; and Fui-Hoon Nah, Fiona, "Use of a Classroom Response System to Enhance Classroom Interactivity" (2006). Management Department Faculty Publications. 26.

https://digitalcommons.unl.edu/managementfacpub/26

This Article is brought to you for free and open access by the Management Department at DigitalCommons@University of Nebraska - Lincoln. It has been accepted for inclusion in Management Department Faculty Publications by an authorized administrator of DigitalCommons@University of Nebraska - Lincoln. 


\title{
Use of a Classroom Response System to Enhance Classroom Interactivity
}

\author{
Keng Siau, Hong Sheng, and Fiona Fui-Hoon Nah
}

\begin{abstract}
Classroom interactivity is a critical component of teaching and learning. This paper reports on the use of a classroom response system to enhance classroom interactivity in a systems analysis and design course. The success of the project was assessed using both quantitative and qualitative data. A pretest/posttest design was used to examine the effects of a classroom response system on interactivity. The results show that a classroom response system can significantly improve classroom interactivity. Qualitative data was also collected to identify the strengths and weaknesses of using a classroom response system to enhance classroom interaction. Based on the quantitative and qualitative results, suggestions and guidelines on using a classroom response system in the classroom settings are discussed.
\end{abstract}

Index Terms-Classroom interactivity, classroom response system, interactivity instrument, mobile education, mobile and wireless technology.

\section{INTRODUCTION}

$\mathbf{I}$ NTERACTIVITY is a very important component of teaching and learning and is considered a key to success in traditional classrooms [1], [2]. Enhancing interaction in the classroom can lead to better and more effective learning [3]-[5]. Oral questioning and answering, which is the most common form of interaction between instructors and students, is used to engage and involve students actively in the classroom, evaluate students' learning and provide informative feedback to students [6]. However, lack of interactivity has been diagnosed as one of the major pedagogical issues facing many educational institutions [7]. Many obstacles inhibit interactions between students and instructors in the traditional classrooms, such as limited class time, rigid seating arrangement, and students' reservations to speak out in class [6], [7].

Technologies, when embedded in instruction to support the cognitive and social processes of learning, can provide unique opportunities for educators [8]. Classroom response system, a system that uses state-of-the-art wireless handheld transmitters (clickers) to capture student votes and transmit data via infrared signals, is designed to collect and aggregate student responses instantly and display the aggregated results in the class. When included in curriculum design, a classroom response system provides a new dimension for interactivity in the classroom and can change the way students and instructors interact in the classroom.

Manuscript received January 16, 2005; revised June 5, 2006.

The authors are with the Department of Management, University of Nebraska-Lincoln, Lincoln, NE 68588-0491 USA (e-mail: ksiau@unl.edu).

Digital Object Identifier 10.1109/TE.2006.879802
With the objective of providing a more dynamic and active learning and teaching environment in the classroom, the instructor of a systems analysis and design class-which is an undergraduate/graduate course offered to management information systems, computer science, and engineering students in a large public university-adopted the classroom response system to support the classroom instruction. This paper reports the use of a classroom response system in the class and discusses the effect of the classroom response system on interactivity in the classroom. Qualitative data was also collected to highlight the benefits and problems in using the classroom response system.

\section{IMPORTANCE OF INTERACTIVITY IN LEARNING}

Interactivity is a critical variable in learning [5]. Student-teacher interaction is ranked highly among factors influencing learning [9]. When students interact with instructors, they are more actively engaged in learning [9].

Interactivity has been recognized as a key factor in education. Various definitions for interactivity have been proposed [5]. In an effort to synthesize these definitions, [5] classified the definitions of interactivity into five categories: 1 ) interactivity can be defined as active involvement of learners; 2) interactivity has been defined based on the patterns of communication among learners/instructors; 3 ) interactivity is defined as instructor-learner communication; 4) interactivity is considered as social, cooperative, or collaborative exchanges; and 5) interactivity can be viewed as a range of instructional activities and technologies. According to [10], communication and engagement are considered as the two most important characteristics of interactivity.

When interactivity is present in the classroom, students are not only more motivated to learn, but also more attentive, more participative, and more likely to exchange ideas with instructors and fellow students [6], [10]. Moreover, interactivity in the classroom will influence students' learning outcomes, such as attitude and achievement [11].

The concept of interactivity, therefore, can be linked to three key theories of learning: behaviorist, cognitivist, and constructivist [10], [11]. Interactivity can support these different types of learning [11]. Behaviorists emphasized the importance of feedback and student self-assessment in learning, which can be achieved through increased interactivity in instructional design. Cognitivists focused on knowledge transfer from instructors to students. Questioning and answering, informative feedback, and explanations are effective ways to improve knowledge transfer, which are different aspects of interactivity in the classroom. The 
constructivist model of learning requires the process of equilibration, that is, the internal process of a learner to organize pieces of information into a system of knowledge. The constructivist learning model suggests that learners' engagement and attention are important in learning.

Interactivity can have significant impact on pedagogy. Given the importance of interactivity in teaching and learning, efforts have been taken by educators to increase classroom interactivity. Information technology can be embedded in curriculum design to deliver educational activities more efficiently and effectively and to facilitate participation and interaction among students. A classroom response system, which is designed to improve questioning and answering in the classroom and to provide instant feedback to instructors and students, was implemented in a systems analysis and design class. An instrument was developed and validated to assess interactivity empirically in the classroom and to assess the outcome of using the classroom response system in the system analysis and design class.

\section{ClassRoom Response System}

\section{A. Systems Analysis and Design Course}

The systems analysis and design course was offered in a large public university to both undergraduate and graduate students in several areas, including Management Information Systems, Computer Science, and Engineering. The system analysis and design course is a 16-week semester course that introduced students to the concepts, processes, software tools, and modeling techniques used in systems analysis, design, and implementation. The course was conducted in a traditional classroom and was mainly lecture based. Before implementing a classroom response system in the classroom, oral questioning and answering was the main mechanism for facilitating instructor/student interaction.

\section{B. Pedagogical Issue}

Interactivity in a classroom is typically limited for the following reasons: 1) class time is limited; 2) in oral questioning and answering, only one student (or the instructor) can talk at any one time, thus student participation is limited; 3) students may not be willing to express their opinions in front of the class for fear that they may embarrass themselves if they say something incorrectly; and 4) no mechanisms are available for instructors to assess whether students are following the course materials and whether there is a need to adjust the pace of teaching.

In Fall 2004, the instructor of a systems analysis and design course adopted a classroom response system with the goal of increasing interactivity in the classroom.

\section{Hyper-Interactive Teaching Technology (H-ITT)}

Hyper-Interactive Teaching Technology (H-ITT) was the classroom response system adopted. It provides a technology-enabled learning environment for enhancing interactivity in the classroom by collecting, aggregating, and displaying students' responses in the classroom. The H-ITT software allows instructors to include some questions (either multiple-choice questions or true-false questions) in PowerPoint slides during the lectures. Students can answer the questions by pressing the respective buttons on the clickers. Students' responses are captured, analyzed, and displayed instantaneously. Therefore, students can get instant feedback on how they are doing in the class; they are also able to gauge their progress in terms of their understanding of the course materials. For instructors, the classroom response system provides a way to engage students in the class, assess whether the students are following the course materials, and evaluate the students' overall understanding in the class so that the pace of instruction can be adjusted accordingly if needed.

\section{Assessment OF H-ITT ProJECT}

\section{A. Hyper-Interactive Teaching Technology}

To assess the effect of the classroom response system on interactivity in the classroom, a pretest/posttest design was adopted. The assessment consists of four parts.

1) Pretest: Before implementing the H-ITT classroom response system in the classroom, each student was given a pretest questionnaire to evaluate his/her level of interactivity in the classroom and the overall interactivity of the class. The pretest was conducted in the middle of the semester before the classroom response system was introduced.

2) Implementation of the classroom response system in the classroom: After the pretest, the H-ITT classroom response system was introduced in the class. In other words, the first half of the semester was conducted in the traditional way, and the second half was supported by the classroom response system.

3) Posttest: After implementing the H-ITT classroom response system in the class for eight weeks (i.e., during the second half of the semester), a posttest questionnaire was given to the students to capture their individual interactivity and the overall interactivity in the classroom. Perceived usefulness and perceived ease of use of the technology were also captured in the questionnaire. Perceived ease of use and perceived usefulness were adopted from the Technology Acceptance Model (TAM) [12], [13] and are used to predict users' intention to use new information technology. Perceived usefulness is defined as the extent to which a person believes that using a particular technology will enhance his or her performance, and therefore, is an indicator of an individual's extrinsic motivation to use a technology. Perceived ease of use refers to the degree to which a person believes that the use of a particular technology will be free of effort, and is, therefore, an indicator of an individual's intrinsic motivation to use a technology [12].

4) Qualitative data collection: In the posttest questionnaire, an open-ended question was included to collect qualitative data on the use of the classroom response system. The question is: "What are the advantages and disadvantages of using the clickers (the classroom response system) in the classroom?"

Twenty-six students took part in both the pretest and posttest and provided qualitative comments regarding the use of classroom response system in the systems analysis and design class. 


\section{B. Instrument Development and Validation}

Although interactivity is considered important in teaching and learning, no instrument for measuring interactivity has been developed. Most of the prior studies are either conceptual in nature [2], [5], [8]-[10] or merely reporting applications [14], [15]. Thus, an instrument for measuring classroom interactivity was developed and validated in this research.

To examine the effect of the classroom response system on interactivity in the classroom accurately and systematically, conceptual definitions from prior literatures were reviewed to develop the instruments (see Appendix). Ten items were developed to measure the construct of interactivity.

According to [5] and [10], interactivity is the active involvement and participation of students in the classroom. As explained in Section II, interactivity is important in different types of learning. From the behaviorist theory, feedback and student self-assessment are two of the most important forms of interaction that should be incorporated in instructional design. Based on the cognitive theory, feedback, questioning, and answering are features of interactivity that can improve students' learning. The constructivist model of learning suggests that learners' engagement and attention are important in learning. Therefore, one may conclude that interactivity can be measured through 1) students' involvement in the class (items 1 and 2);2) students' engagement in the class (items 3 and 4); 3) students' participation in the class (items 5 and 6); 4) students receiving feedback from instructors (items 7 and 8); and 5) students' self-assessment (items 9 and 10). (Refer to Appendix for the items.) Each question is measured using a nine-point Likert scale with 1 representing "strongly disagree" and 9 representing "strongly agree."

Also, individual interactivity may be different from overall classroom interactivity. For example, the overall level of interactivity may be high (i.e., most students participate in discussion and interact with the instructor), but specific students may not be participating and hence, their individual interactivity will be low. Therefore, individual interactivity and overall classroom interactivity were measured separately.

A pilot study was conducted to test the reliability of the instruments. One hundred and thirty-eight undergraduate students attending an introduction to a computer information systems class took part in the pilot study. The reliability of the instruments was assessed. The Cronbach's alpha coefficient for interactivity at the individual level is 0.86 , and for interactivity at the class level is 0.90 . The Cronbach's alpha coefficients for interactivity at both the individual level and the class level exceed Nunnally's [16] threshold of 0.70 , which suggests that the instruments are highly reliable.

The instruments for measuring perceived ease of use and perceived usefulness were adapted from [12] and [13]. (Refer to Appendix for the instruments.)

\section{Assessment Results}

To evaluate the effect of using the classroom response system on interactivity in the classroom, interactivity before and after the implementation of the classroom response system were assessed.
The descriptive statistics indicate that the interactivity at both the individual and class levels increased after using the classroom response system in the classroom. Before the implementation of the classroom response system, the average level of interactivity at the individual level is 6.1 , and that for the overall class interactivity is 6.3. After using the classroom response system, the average level of interactivity at the individual level was increased to 6.8 , and that of the overall class interactivity was increased to 7.1 .

A paired sample T-test was run to test for statistical significance. For interactivity at the individual level, the statistics show that interactivity has been increased significantly $(t=3.537$, $p=0.002$ ). For overall class interactivity, the increase is also statistically significant $(t=4.378, p=0.000)$. The results of the T-tests suggest that the classroom response system significantly increase interactivity at both the individual and class levels.

The reliability of the interactivity instruments was also assessed in the pretest and posttest. In the pretest, the Cronbach's alpha coefficient for individual interactivity is 0.86 , and that for class interactivity is 0.90 . In the posttest, the Cronbach's alpha coefficient for individual interactivity is 0.91 , and that for class interactivity is 0.94 . The very high Cronbach's alpha coefficients indicate that the instruments are highly reliable.

The mean for perceived usefulness is 7.35 (out of 9), and the mean for perceived ease of use is 7.74 (out of 9). The relatively high means suggest that the students perceived the use of the classroom response system to be free of effort, and they believed that using the classroom response system made it easier for them to interact in the classroom. The reliability tests show that the Cronbach's alpha coefficient for perceived usefulness is 0.96 , and that for perceived ease of use is 0.73 . Both are above the 0.70 threshold [16].

The findings clearly show that the classroom response system can effectively enhance interactivity in the classroom. Incorporating the classroom response system in the classroom enables students to participate more in the classroom, provide opinions to questions from the instructor, receive feedback from the instructor during the class regarding their understanding of the course materials, gauge whether they are following the course materials, and assess their understanding of the course materials with respect to the other students in the class. In other words, students are more engaged, more attentive, and more involved in the class. Students perceived the classroom response system (clickers) to be easy to use and useful for their learning.

\section{Suggestions for Using the Classroom RESPONSE SYSTEM}

Qualitative data was collected to understand the strengths and weaknesses of using the classroom response system in the classroom. In the students' responses to the qualitative questions on the advantages and disadvantages of using clickers (the classroom response system) in the classroom, they listed the following advantages: 1) the classroom response system enhances interactivity in the class (students were more involved, attentive, and participative; and they received better and more timely feedback); 2) the classroom response system was fun to use in the class; 3 ) students can vote anonymously using the 
classroom response system; 4) the classroom response system is easy to use; 5) the use of the classroom response system adds technology components to the class; 6) the classroom response system promotes learning; and 7) the use of the classroom response system helps instructors to understand the students' level of understanding so that they can explain concepts to the students better.

Not surprising, interactivity is one of the most highly cited benefits of the classroom response system. Students highlighted that the use of the classroom response system increased their involvement in the class, helped to promote more class participation, allowed them to get immediate feedback, and enabled them to assess their understanding relative to those of the other students. Anonymity is one of the advantages provided by the classroom response system. With the classroom response system, every student has the chance to answer every question without being embarrassed if his or her answer is wrong. The anonymity feature of the classroom response system increases students' willingness to participate in the class.

Fun is another benefit of using the classroom response system. As the students stated, the classroom response system "complements the lectures," "introduces activities during the lectures," and "makes the lectures more interesting." The classroom response system uses a transmitter that is similar to a TV remote control; therefore, the classroom response system is fairly easy to use and operate. Also, since system analysis and design is a course related to technology, students realized the benefit of using advanced technology, such as the classroom response system in the class. Students also believed that with the help of the classroom response system, the instructor was able to explain course materials better. Overall, they felt that the use of the classroom response system in the class promoted interactivity and learning.

The main disadvantages of the classroom response system (the clickers) that were identified by the students are as follows: 1) sometimes the clickers do not function properly; 2) question types are limited to multiple choice questions and true/false questions; 3) some students do not take voting seriously; 4) sometimes using clickers can be distracting; and 5) voting using clickers takes up class time.

The above identified disadvantages are concerned with technology, instructional design, and students' attitudes. First, the classroom response system is a new technology and has room for technological improvement and advancement. For example, students' responses sometimes could not be detected and received by the receiver. The receiver was not able to receive more than one concurrent response, or the transmitter was not within the range of the receiver. Second, the classroom response system can only capture quantitative data, thus limiting the responses to multiple-choice or true-false questions. Third, since using the wireless handheld transmitter was fun to the students, some of them did not take it seriously_by clicking multiple times on purpose, by clicking on answers that were obviously incorrect, or by clicking on answers that were out of the range/choices given. Students also raised concerns relating to instructional design. For example, the following questions should be considered when designing instruction. How much class time should be allocated to voting? What types of questions are appropriate for use with the classroom response system? And will the use of the classroom response system disrupt the pace and flow of the class?

The advantages and disadvantages identified by the students not only provide a more comprehensive picture and understanding of using the classroom response system in the classroom, but also provide additional information that is useful to educators planning to implement the classroom response system. These qualitative comments highlight a number of pedagogical and curriculum issues that are valuable to educators.

1) Interactivity has long been considered one of main pedagogical issues in the classroom, especially for large classes and technology-related courses. The results of this study suggest that the classroom response system is an effective way to improve interactivity in the classroom. The students' comments also indicate that interactivity promotes learning.

2) The success of using the classroom response system in the classroom also suggests that technology components should be part of the curriculum design for classes related to technology. For example, adoption of a state-of-art technology can improve students' interests and motivation in learning the course materials. In this study, the classroom response system was successfully utilized in a system analysis and design class, which is a technically oriented course.

3) Technology should be working. Not only must the technology be easy to use, it must also be useful and working properly. A technology that is not working properly can create frustrations and disrupt the learning process. For example, the transmitters should be checked before the class to ensure that the batteries are not depleted. When using a classroom response system, instructors need to make sure that the signals sent out from the transmitters (clickers) are within the range of the receivers and can be successfully captured by the receivers. A few spare transmitters (clickers) should be made available in the classroom in case some do not work properly. If the classroom is large, several receivers are necessary.

4) Instructors need to integrate the classroom response system seamlessly in the curriculum design. Although the classroom response system is an effective way for enhancing classroom interactivity, it may disrupt the pace and flow of the lecture if it is not implemented with care. Instructors need to design the questions carefully to complement the lectures. When designing the instruction, instructors also need to consider when to introduce the questions, what questions to ask, and how much class time to allocate. Instructors should also be flexible to adjust the pace of lecturing based on the students' responses gathered using the classroom response system.

\section{RELATED WORK}

A number of studies in the literature have reported the adoption of classroom response systems that are similar to H-ITT. Early adopters of classroom response systems have consistently described the technology as a catalyst for a significant, powerful shift in the classroom climate, pedagogy, and resulting 
learning. Studies have also attempted to evaluate interactivity in the classroom after using classroom response systems. For example, [6] evaluated the use of a specific interactive response system-EduClick in a K-12 school—and suggested that using EduClick during instruction and learning could increase the utility rate and utility time of classroom computers, enhance students' motivation and attention, and promote quality of teaching. However, the research did not use any empirically validated instruments to assess EduClick. The results were collected by simply asking students whether EduClick improved the quality of teaching, the students' motivation, and their attention. The reliability and validity of the results may be questioned.

An application that uses an electronic voting system in lectures on logic was reported in [14]. These authors also identified benefits and disadvantages of using the technology. Similarly, [7] presented a project on introducing electronic voting equipment for lectures in various departments, such as Computer Science, Psychology, Medicine, and Statistics. They identified benefits and problems with using the classroom response system's handsets in lectures, and then asked students to rank-order them. The advantages and disadvantages derived in the above studies correspond closely to the qualitative data analysis in the current study.

Although several researchers have studied the use of the classroom response system which is similar to H-ITT, systematic assessments of the usefulness and effectiveness of the classroom response system for enhancing interactivity are lacking. Most of the existing studies on interactivity used ad hoc questionnaires and observations for assessment. In the current study, the researchers employed reliable and validated instruments to capture individual interactivity, classroom interactivity, perceived ease of use, and perceived usefulness. Qualitative data was also collected to provide a deeper understanding of the strengths and weaknesses of the classroom response system.

\section{CONCLUSION}

The advancement of mobile and wireless technology has helped to improve commerce [17]-[19], services [20], [21], and supply chain management [22], [23]. Mobile technology is considered to be strategic to many organizations and activities [24], [25]. Education is no exception. A mobile classroom response system has the potential to enhance and improve education. This research is one of the first studies that empirically evaluated the effect of the classroom response system in an information technology class. The results show that the classroom response system can significantly improve interactivity in the classroom.

APPENDIX

INSTRUMENTS FOR STUDY

\section{Individual Degree of Interactivity (1: strongly disagree, 9: strongly agree)}

1. I interact with the instructor in class.

2. I am involved in learning during class.

3. I am engaged in class.

4. I am attentive in class.
5. I participate in class discussion.

6. I provide my opinion to questions from the instructor during the class.

7. I receive feedback in class on my understanding of the course materials.

8. I receive feedback from the instructor during the class.

9. I can gauge whether I am following the course materials during the class.

10. I can assess my understanding of the course materials with respect to other students during the class.

\section{Overall Degree of Interactivity (1: strongly disagree, 9 : strongly agree)}

1. Students interact with the instructor in class.

2. Students are involved in learning during class.

3. Students are engaged in class.

4. Students are attentive in class.

5. Students participate in class discussion.

6. Students provide their opinions to questions from the instructor during the class.

7. Students receive feedback in class on their understanding of the course materials.

8. Students receive feedback from the instructor during the class.

9. Students can gauge whether they are following the course materials during the class.

10. Students can assess their understanding of the course materials with respect to other students during the class.

\section{Perceived Ease of Use (1: strongly disagree, 9: strongly agree)}

1. It is easy for me to become skillful at using the clickers.

2. I find it easy to get the clickers to work as intended.

3. I find the clickers easy to use.

\section{Perceived Usefulness (1: strongly disagree, 9: strongly agree)}

1. Using the clickers increases my interaction in the class.

2. Using the clickers makes it easier for me to interact in the class.

3. I find the clickers useful in enhancing my interaction in the class.

\section{REFERENCES}

[1] C. P. Fulford and S. Zhang, "Perceptions of interaction: The critical predictor in distance education," Amer. J. Distance Educ., vol. 7, no. 3, pp. 8-21, 1993.

[2] C. Chou, "Interactivity and interactive functions in web-based learning systems: A technical framework for designers," Br. J. Educ. Technol., vol. 34, no. 3, pp. 265-279, 2003.

[3] J. Erickson and K. Siau, "E-ducation," Commun. ACM, vol. 46, no. 9, pp. 134-140, 2003.

[4] C. Evans and K. Sabry, "Evaluation of the interactivity of Web-based learning systems: Principles and process," J. Innovations Educ. Teaching Int., vol. 40, no. 1, pp. 89-99, 2003.

[5] B. Bannan-Ritland, "Computer-mediated communication, elearning, and interactivity: A review of the research," Quart. Rev. Distance Educ., vol. 3, no. 2, pp. 161-179, 2002. 
[6] T. Liu, J. Liang, H. Wang, T. Chan, and L. Wei, "Embedding educlick in classroom to enhance interaction," in Proc. Int. Conf. Computers in Education (ICCE)., Hong Kong, China, pp. 117-125.

[7] S. W. Draper and M. I. Brown, "Increasing interactivity in lectures using an electronic voting system," J. Comput. Assist. Learn., vol. 20, pp. 81-94, 2004.

[8] M. D. Roblyer and W. R. Wiencke, "Design and use of a rubric to assess and encourage interactive qualities in distance courses," Amer. J. Distance Educ., vol. 17, no. 2, pp. 77-98, 2003.

[9] M. C. Wang, G. D. Haertel, and H. J. Walberg, "What influences learning? A content analysis of review literature," J. Educ. Res., vol. 84, no. 1, pp. 30-43, 1992.

[10] R. Sims, "Promises of interactivity: Aligning learner perceptions and expectations with strategies for flexible and online learning," Distance Educ., vol. 24, no. 1, pp. 87-103, 2003.

[11] W. D. Haseman, V. N. Polatoglu, and K. Ramamurthy, "An empirical investigation of the influences of the degree of interactivity on useroutcomes in a multimedia environment," Inform. Resources Manage. J., vol. 15, no. 2, pp. 31-48, 2002.

[12] F. Davis, "Perceived usefulness, perceived ease of use and user acceptance of information technology," MIS Quart., vol. 13, no. 3, pp. 319-340, 1989.

[13] F. Davis, R. P. Bagozzi, and P. R. Warshaw, "User acceptance of computer technology: A comparison of two theoretical models," Manage. Sci., vol. 35, no. 8, pp. 982-1003, 1989.

[14] S. A. Struart, M. J. Brown, and S. W. Draper, "Using an electronic voting system in logic lectures: One practitioner's application," $J$. Comput. Assist. Learn., vol. 20, pp. 95-102, 2004.

[15] S. Davis, "Observations in classrooms using a network of handheld devices," J. Comput. Assist. Learn., vol. 19, pp. 298-307, 2003.

[16] J. Nunnally, Psychometric Theory. New York: McGraw-Hill, 1978.

[17] K. Siau, E. Lim, and Z. Shen, "Mobile commerce—Promises, challenges, and research agenda," J. Database Manage., vol. 12, no. 3, pp. 4-13, 2001.

[18] K. Siau and Z. Shen, "Building customer trust in mobile commerce," Commun. ACM, vol. 46, no. 4, pp. 91-94, 2003.
[19] K. Siau, H. Sheng, F. Nah, and S. Davis, "A qualitative investigation on consumer trust in mobile commerce," Int. J. Electron. Bus., vol. 2 , no. 3, pp. 283-300, 2004.

[20] I. Grant, "The mobile revolution: The making of mobile services worldwide," Int. J. Advertising, vol. 25, no. 1, pp. 119-120, 2006.

[21] K. Siau and Z. Shen, "Mobile communications and mobile services," Int. J. Mobile Commun., vol. 1, no. 1/2, pp. 3-14, 2003.

[22] T. Eng, "Mobile supply chain management: Challenges for implementation," Technovation, vol. 26, no. 5/6, pp. 682-686, 2006.

[23] K. Siau and Z. Shen, "Mobile commerce applications in supply chain management," J. Internet Commerce, vol. 1, no. 3, pp. 3-14, 2002.

[24] F. Nah, K. Siau, and H. Sheng, "The value of mobile applications: A utility company study," Commun. ACM, vol. 48, no. 2, pp. 85-90, 2005.

[25] H. Sheng, F. Nah, and K. Siau, "Strategic implications of mobile technology: A case study using value-focused thinking," J. Strategic Inf. Syst., vol. 14, no. 3, pp. 269-290, 2005.

Keng Siau is a Professor of Management Information Systems (MIS) at the University of Nebraska-Lincoln.

His research interests include systems analysis and design, mobile commerce and ubiquitous commerce, and user-database interaction.

Hong Sheng is an Assistant Professor at the University of Missouri-Rolla. Her research interests include mobile commerce and ubiquitous commerce, and human-computer interaction.

Fiona Fui-Hoon Nah is an Associate Professor of Management Information Systems (MIS) at the University of Nebraska-Lincoln.

Her research interests include mobile education, mobile and ubiquitous commerce, human-computer interaction, and computer-supported collaborative work. 